\title{
PENGARUH PEMBIAYAAN, SIMPANAN MUDHARABAH, DAN BIAYA OPERASIONAL BANK TERHADAP SYARIAH MUQASHID INDEX PADA BANK UMUM SYARIAH DI INDONESIA
}

\author{
Ririn Sari Dewi \\ Universitas Pamulang \\ al.rizky26@yahoo.com
}

\begin{abstract}
The purpose of this research is to analyse the influence of the Financing, Mudharabah Saving Account, and the Bank Operational Cost to the Syariah Muqasid Index of the Bank Umum Syariah (BUS) in Indonesia, The researcher use 55 sample of 11 Bank Umum Syariah (BUS) in Indonesia within 5 years of annual report period. In this research, the researcher use the Multiple Regression af statistical method to analyse the data. The result of this research shows that the Financing, Mudharabah Saving Account, and the Bank Operational Cost has positive influence simultaneously to the Syariah Muqasid Index, and the Financing has positive influence simultaneously to the Syariah Muqasid Index, and the Mudharabah Saving Account has positive influence simultaneously to the Syariah Muqasid Index. And researcher has found that the Mudharabah Saving Account variable has no influence directly to the performance of the Syariah Muqasid Index, because the Mudharabah Saving Account variable is distributed by the bank to the Financing Variable depends on the needs of the bank customers dan the result is divided by the profit sharing according the understanding which is made in the first MOU.
\end{abstract}

KeyWords :the Financing, Mudharabah Saving Account, and the Bank Operational Cost to the Syariah Muqasid Index of the Bank Umum Syariah (BUS) in Indonesia

\section{PENDAHULUAN}

Perkembangan di dunia perbankan syariah mengalami kemajuan yang sangat pesat dalam kurun waktu beberapa dekade ini. Dimulai awal tahun 1990 telah terealisasi ide tentang pendirian bank Syariah di Indonesia yang merupakan bentuk penolakan terhadap sistem riba yang bertentangan dengan hukum Islam. Keunikan bank syariah dalam hal compliance yaitu pemenuhan hukum Islam dalam operasionalnya tidak bisa disama ratakan dengan pengukuran yang sama dengan bank konvensional. Pengukuran kinerja perbankan syariah dapat dilakukan dengan maqasid syari'ah. Dalam maqasid syari'ah akan diketahui kinerja perbankan atau 
aktifitas muamalah yang dijalankan bank syariah tersebut sudah memenuhi nilainilai dan prinsip-prinsip yang disyariatkan Islam atau belum.

Pelaksanaan maqasid syari'ah dalam bank syariah telah menjadi perhatian beberapa peneliti muslim. Seperti Mustafa Omar (2008) yang merumuskan pengukuran kinerja keuangan syariah yang dikembangkan berdasarkan prinsipprinsip maqasid syari;ah yang disebut dengan syari'ah maqasid index (SMI). Pengukuran SMI diadaptasi dari pemikiran Muhammad Abu Zahrah (1997) dalam kitabnya "Usul Al Fiqh" dimana tujuan dari maqasid syari'ah ada tiga yaitu: tahzib al fard (mendidik manusia), iqamah al 'adl (menegakkan keadilan), dan jalb al maslahah (kebaikan untuk umat) yang diukur melalui beberapa parameter berdasarkan aspek tersebut.

Dalam teory Tata kelola perusahaan yang baik, yang dalam terminologi modern disebut sebagai Good Corporate Governance berkaitan dengan hadits Rasulullah SAW yang diriwayatkan oleh Aisyah r.a yang artinya "Sesungguhnya Allah menyukai apabila seseorang melakukan sesuatu pekerjaan dilakukan dengan baik". Prinsip- prinsip yang dianut dalam teori good corporate governance dalam islam adalah : 1. Tauhid merupakan prinsip dasar tertinggi dari semua kegiatan hidup ummat Islam, dan menjadi pegangan setiap Muslim tanpa membedakan madzhab ataupun aliran yang dianutnya. 2. Taqwa dan ridha : Prinsip atau azas taqwa dan ridha menjadi prinsip utama tegaknya sebuah institusi Islam dalam bentuk apapun azas taqwa kepada Allah dan ridha-Nya.

Menurut Siddiqi (1980), bank Syariah harus memiliki tujuan yang jauh lebih besar dibandingkan hanya untuk mencapai laba maksimum dan juga harus berusaha untuk mewujudkan Maqashid Syariah. Menurut Chapra (2001), untuk dapat mencapai Maqashid Syariah, sebuah lembaga bisnis Syariah harus mampu untuk melakukan penjagaan pada al-aql (pikiran), addien (agama), nafs (jiwa), nasl (keturunan), maal (harta). Dalam konteks praktik bisnis Syariah, pencapaian Maqashid Syariah dapat diukur melalui pencapaian tujuan berupa pendidikan individu, penciptaan keadilan dan pencapaian kepentingan publik dimana tiga faktor tersebut sesuai dengan tujuan umum maqasyid syariah yaitu "mencapai kesejahteraan dan menghindari keburukan”. Ketiga tujuan ini bersifat universal yang 
seharusnya menjadi tujuan dan dasar operasional setiap entitas berakuntabilitas publik, tidak hanya bank syariah tetapi juga bank konvensional, karena berkaitan dengan kesejahteraan bagi semua pemangku kepentingan, bukan hanya pemegang saham atau pemilik perusahaan. (Abu Zaharah, 1997; sebagaimana yang dikutip oleh Mohammed dan Taib, 2009).

\section{TELAAH LITERATUR DAN PENGEMBANGAN HIPOTESIS}

\section{Tinjauan Teori}

\section{Teori Good Corporate Governance}

Islam mempunyai konsep yang jauh lebih lengkap dan lebih komprehensif serta akhlaqul karimah dan ketaqwaan pada Allah SWT yang menjadi tembok kokoh untuk tidak terperosok pada praktek ilegal dan tidak jujur dalam menerima amanah. Tata kelola perusahaan yang baik, yang dalam terminologi modern disebut sebagai Good Corporate Governance berkaitan dengan hadits Rasulullah SAW yang diriwayatkan oleh Aisyah r.a yang artinya "Sesungguhnya Allah menyukai apabila seseorang melakukan sesuatu pekerjaan dilakukan dengan baik". Good Corporate Governance dalam Islam harus mengacu pada prinsip-prinsip berikut ini.

1. Tauhid

Tauhid merupakan prinsip dasar tertinggi dari semua kegiatan hidup ummat Islam, dan menjadi pegangan setiap Muslim tanpa membedakan madzhab ataupun aliran yang dianutnya.

2. Taqwa dan ridha

Prinsip atau azas taqwa dan ridha menjadi prinsip utama tegaknya sebuah institusi Islam dalam bentuk apapun azas taqwa kepada Allah dan ridha-Nya.

3. Ekuilibrium (keseimbangan dan keadilan)

Tawazun atau mizan (keseimbangan) dan al-'adalah (keadilan) adalah dua buah konsep tentang ekuilibrium dalam Islam.

4. Kemashlahatan

Penegakan otoritas kepemimpinan dan keagamaan dalam rangka menjaga keharmonisan fisik maupun sosial, dimaksudkan pula untuk memenuhi tujuan 
diterapkannya syari'ah Islam (maqashidusy-syari'ah) yaitu mencapai kemaslahatan ummat manusia secara keseluruhan, sebagai perwujudan dari kehendak Islam kenjadi rahmat bagi semesta alam.

\section{Teori kinerja menurut pandangan Islam}

1. Telaah teks tentang kinerja

Pengertian kinerja atau prestasi kerja ialah kesuksesan seseorang di dalam melaksanakan pekerjaan. sejauh mana keberhasilan seseorang atau organisasi dalam menyelesaikan pekerjaannya disebut "level of performance".

2. Telaah teks Al- Qur'an tentang kinerja

Firman Allah dalam Al-Qur'an surat Al-Ahqaaf ayat 19

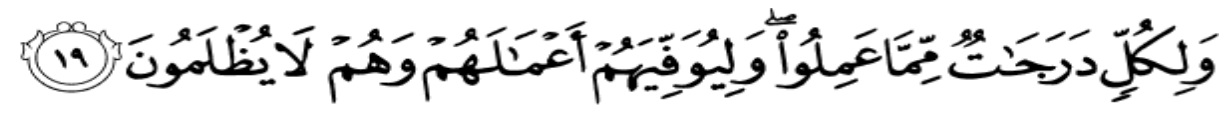

"Dan bagi masing-masing mereka derajat menurut apa yang Telah mereka kerjakan dan agar Allah mencukupkan bagimereka (balasan) pekerjaan pekerjaan mereka sedang mereka tiada dirugikan”.

\section{Pembiayaan}

Pembiayaan merupakan salah satu tugas pokok bank, yaitu pemberian fasilitas penyediaan dana untuk memenuhi kebutuhan pihak-pihak yang merupakan defisit unit(peminjam) . (Antonio, 2007)

\section{Simpanan Mudharabah}

Tabungan Mudharabah adalah simpanan yang penarikannya hanya dapat dilakukan menurut syarat-syarat tertentu (sesuai dengan perjanjian atau kesepakatan yang telah dibuat antara bank dan nasabah atau si penabung).

\section{Biaya Operasional}

Biaya operasi merupakan salah satu elemen yang paling penting dalam aktivitas ekonomi pada suatu perusahaan dalam pembentukan laba. Menurut Nafarin (2004) menyatakan bahwa, "Biaya operasi adalah seluruh pengeluaran yang terjadi dalam suatu organisasi guna pelaksanaan aktivitas serta pencapaian tujuan yang telah ditentukan". 


\section{Syariah Muqasid Index}

Syariah Muqasid Index merupakan metode pengukuran kinerja perbankan syariah yang dikembangkan oleh Mustafa Omar Muhammed dalam penelitiannya merumuskan sebuah pengukuran yang berguna untuk mengukur kinerja perbankan syariah yang dikembangkan berdasarkan prinsip-prinsip maqasyid syariah dengan tujuan agar ada sebuah pengukuran bagi bank syariah yang sesuai dengan tujuannya.

\section{Pengembangan Hipotesis}

\section{Pengaruh pembiayaan terhadap syariah muqasid index}

Penelitian mengenai pembiayaan terhadap syariah muqasid index telah dilakukan oleh Whedy Prasetyo (2011), pembiayaan bagi hasil secara parsial memiliki pengaruh positif terhadap laba, yang memberikan penjelasan bahwa semakin besar pembiayaan bagi hasil, semakin besar pula laba yang diperoleh. Berdasarkan hasil penelitian tersebut menunjukkan hasil yang tidak konsisten sehingga perlu dilakukan penelitian lanjutan.

\section{H2: Pembiayaan berpengaruh positif terhadap syariah muqasid index}

\section{Pengaruh simpanan mudharabah terhadap syariah muqasid index}

Penelitian mengenai pengaruh simpanan mudharabah terhadap syariah muqasid index ini berkaitan dengan penelitian terdahulu yang telah dilakukan oleh penelitian sebelumnya yang dilakukan Nurdin (2005) yang menjelaskan bahwa tabungan mudharabah baik secara parsial maupun simultan mempengaruhi pembentukan laba. Penelitian Nurdin didukung oleh Lutfiyah (2015), Dina (2015) Hasil penelitian menunjukkan bahwa Tabungan Mudharabah dan Deposito Mudharabah memiliki pengaruh tidak signifikan terhadap laba yang dapat diidentifikasi dari taraf signifikansi Tabungan Mudharabah yaitu 0,293 lebih besar dari 0,05 dan Deposito Mudharabah yaitu 0,136 lebih besar dari 0,05.

H3: Simpanan Mudharabah berpengaruh positif terhadap syariah muqasid index 


\section{Pengaruh biaya operasional terhadap syariah muqasid index}

Penelitian mengenai pengaruh biaya operasional terhadap syariah muqasid index telah diteliti oleh Juki (2008) meneliti pengaruh biaya operasi terhadap profitabilitas pada PT. Kereta Api Indonesia (Persero). Hasil penelitian tersebut menyatakan variabel biaya pokok penjualan, biaya pemasaran, serta biaya administrasi dan umum berpengaruh negatif dan signifikan terhadap profitabilitas.

H4: Biaya Operasional berpengaruh positif terhadap syariah muqasid index.

\section{Model Penelitian}

Model Penelitian dalam penelitian ini adalah sebagai berikut:

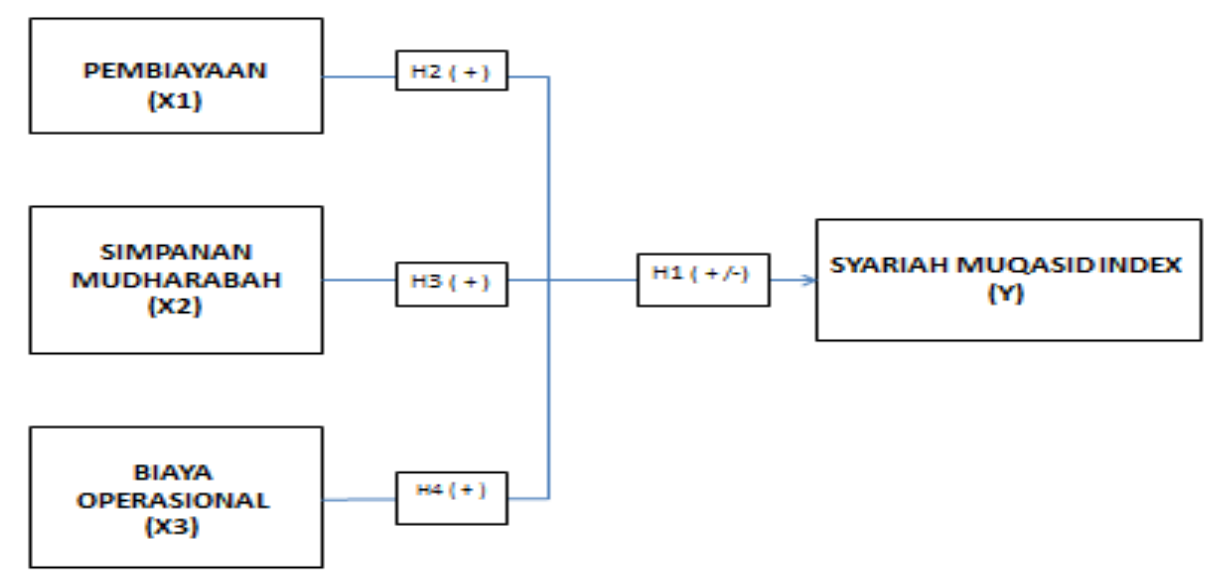

Gambar 2.1

Model Penelitian

Keterangan:

H1 : Pembiayaan, simpanan mudharabah, biaya operasional bank memiliki pengaruh positif terhadap Syariah Muqasid Index 


\section{METODE PENELITIAN DAN PEMBAHASAN}

\section{METODE PENELITIAN}

Penelitian ini merupakan studi kasus yang dilakukan untuk membuktikan adanya hubungan eksplonatoris kausalitas antara Pembiayaan, Simpanan Mudharabah, dan Biaya Operasional Bank dengan Syariah Muqasid Index. Penelitian ini merupakan pengujian hipotesis yang diajukan terkait dengan pengaruh antara variabel independen terhadap variabel dependen.

Unit analisis perusahaan bank syariah sumber data adalah annual report yang telah dipublikasikan oleh bank umum syariah diIndonesia yang masih beroperasi. Populasi dalam penelitian ini adalah bank umum syariah yang beroperasi di Indonesia. Jumlah populasi dalam penelitian ini adalah 11 bank syariah. Untuk menentukan sampel dalam penelitian ini sampel yang digunakan adalah bagian dari populasi. Sampel dalam penelitian ini dipilih berdasarkan metode sampling jenuh, yakni sampel teknik pengambilan sampel apabila semua populasi digunakan sebagai sampel dan dikenal juga dengan istilah sensus, dengan jumlah sampel 55.

Jenis data penelitian ini adalah data kuantitatif dengan pendekaan deskriptif yang berasal dari laporan keuangan tahunan bank umum syariah. Sumber data penelitian ini seluruhnya adalah data sekunder eksternal, yaitu data yang tidak langsung di dapat dari perusahaan, tapi diperoleh dalam bentuk data yang telah dikumpulkan, diolah dan dipublikasikan oleh pihak lain yaitu otoritas jasa keuangan. Metode pengumpulan data yang digunakan dalam penelitian ini adalah observasi non prilaku. Observasi non prilaku adalah metode pengumpulan data dimana peneliti tidak terlibat dan hanya sebagai pengamat independen.

Variabel pembiayaan, Simpanan Mudharabah, Biaya Operasional dan Syariah Muqasid Index yang dikembangkan oleh beberapa peneliti yaitu, Theresia dan Tendelilin, Karim, Nafarin, dan Muhammad, diisi dengan lima skala nominal dan skala rasio. Uji hipotesis dilakukan dengan menggunakan Regresi Linear Berganda dengan Program SPSS 21. 


\section{HASIL PENELITIAN DAN PEMBAHASAN}

\section{Hasil}

\section{Statistik Deskriftif}

Analisis deskriptif dari masing - masing variabel pada Bank Umum Syariah selama tahun 2011 - 2015 dapat dilihat pada tabel di bawah ini :

Tabel 4.1

Hasil Statistik Deskriptif Descriptive Statistics

\begin{tabular}{|l|l|l|l|l|l|}
\hline & $\mathrm{N}$ & Minimum & Maximum & Mean & $\begin{array}{l}\text { Std. } \\
\text { Deviation }\end{array}$ \\
\hline PEMBIAYAAN & 55 & .00 & 21274.00 & 3607.9636 & 5615.29907 \\
MUDHARABAH & 55 & .00 & 21942.00 & 3125.4364 & 5925.98464 \\
OPERASIONAL & 55 & 17.00 & 4091.00 & 777.0727 & 998.15450 \\
SMINDEX & 55 & .09 & .41 & .3018 & .08258 \\
Valid N (listwise) & 55 & & & & \\
\hline
\end{tabular}

Data diolah

Tabel 4.1 di atas menunjukkan bahwa jumlah objek yang diteliti $(\mathrm{N})$ adalah sebanyak 55 sampel dari masing-masing variabel menunjukkan nilai rata-rata secara keseluruhan. Variabel pembiayaan memiliki rata-rata sebesar Rp. 3.607,96 (Milyar), Variabel simpanan mudharabah rata - rata Rp. 3.125,43 (Milyar), dan variabel biaya operasional Rp. 777,07 (Milyar), sementara syariah muqasid index memiliki ratarata 0,3018 atau $30,18 \%$. 


\section{UJI ASUMSI KLASIK}

\section{Uji Normalitas}

Berikut adalah hasil pengujian normalitas :

Tabel 4.2

Hasil Uji Normalitas Data

One-Sample Kolmogorov-Smirnov Test

\begin{tabular}{|c|c|c|c|c|c|}
\hline & & SMINDEX & LNPEMB & $\begin{array}{l}\text { LNMUD } \\
\text { AR }\end{array}$ & $\begin{array}{l}\text { LNOPERA } \\
\mathrm{S}\end{array}$ \\
\hline \multicolumn{2}{|l|}{$\mathrm{N}$} & 55 & 48 & 50 & 55 \\
\hline & Mean & .3018 & 7.1803 & 6.0153 & 5.7514 \\
\hline Normal Parameters ${ }^{\mathrm{a}, \mathrm{b}}$ & $\begin{array}{l}\text { Std. } \\
\text { Deviation }\end{array}$ & .08258 & 1.80700 & 2.33486 & 1.49219 \\
\hline \multirow{3}{*}{$\begin{array}{l}\text { Most } \\
\text { Differences }\end{array}$} & Absolute & .135 & .116 & .154 & .132 \\
\hline & Positive & .111 & .074 & .154 & .121 \\
\hline & Negative & -.135 & -.116 & -.103 & -.132 \\
\hline \multicolumn{2}{|c|}{ Kolmogorov-Smirnov Z } & 1.001 & .807 & 1.090 & .975 \\
\hline \multicolumn{2}{|l|}{ As ymp. Sig. (2-tailed) } & .269 & .533 & .185 & .297 \\
\hline
\end{tabular}

a. Test distribution is Normal.

b. Calculated from data.

Sumber: Hasil Pengolahan Data SPSS 21.

Dari hasil pengolahan data mentah tersebut variabel pembiayaan, simpanan mudharabah, dan biaya operasional mengalami ketidak normalan karena nilai uji di bawah 0,05, maka variabel tersebut dinormalkan dengan menggunakan Trimming melalui perubahan Log Natural (LN). Hasil dari Run test maka variabel pembiayaan memiliki nilai sig sebesar 0,533 , simpanan mudharabah memiliki nilai 0,185 , dan biaya operasional memiliki 0,297 dari hasil Run test berarti untuk model setiap variabel memiliki nilai sig diatas 0,05 sehingga data terdistribusi normal.

\section{Uji Multikolinieritas}

Untuk mendeteksi multikolinieritas adalah dengan melihat variance inflation factor (VIF), dimana jika nilai VIF $<10$, maka variabel tidak mempunyai persoalan multikolinieritas dengan variabel bebas yang lainnya. 
Tabel 4.3

Hasil Uji Multikolinearitas

Coefficients $^{\mathrm{a}}$

\begin{tabular}{|ll|l|l|}
\hline \multicolumn{2}{|l|}{ Model } & \multicolumn{2}{|c|}{ Collinearity Statistics } \\
\cline { 3 - 4 } & & Tolerance & VIF \\
\hline \multirow{3}{*}{1} & (Constant) & & \\
& LNPEMB & .640 & 1.563 \\
& LNMUDAR & .186 & 5.378 \\
& LNOPERAS & .226 & 4.433 \\
\hline
\end{tabular}

Sumber: Hasil Pengolahan Data SPSS 21.

Pada tabel 4.3 untuk nilai VIF variabel independen tidak terjadi multikolinearitas hal ini terbukti untuk nilai VIF variabel pembiayaan sebesar 1.563, variabel simpanan mudharabah memiliki nilai VIF sebesar 5.378, dan variabel biaya operasional dan di ln kan sebesar 4.433 masing-masing variabel memiliki nilai VIF $<10$ sehingga antara variabel independen tidak terjadi multikolinearitas dan menyimpulkan bahwa uji multikolinearitas terpenuhi.

\section{Uji Autokorelasi}

Diagnosa tidak terjadi autokorelasi dapat dilakukan dengan tabel, yaitu:

Tabel 4.4

Uji Autokorelasi

Model Summary

\begin{tabular}{|l|l|}
\hline Model & Durbin-Watson \\
\hline 1 & 1.366 \\
\hline
\end{tabular}

a. Predictors: (Constant), LNOPERAS, LNPEMB, LNMUDAR

b. Dependent Variable: SMINDEX

Sumber: Hasil Pegolahan Data SPSS 21.

Pada tabel 4.4 nilai DW pada model summary menunjukkan hasil sebesar 1,366. Karena nilai 1,366 terletak diantara $-2<1,366<+2$ maka dapat disimpulkan bahwa nilai DW tersebut berada pada interval tidak terjadi autokorelasi. Hasil pengujian ini menunjukkan bahwa model regresi ini terbebas dari autokorelasi. 


\section{Uji Heterokedastisitas}

Berikut adalah hasil dari uji heteroskedastisitas dalam penelitian ini

Gambar 4.1

Uji Heterokedastisitas

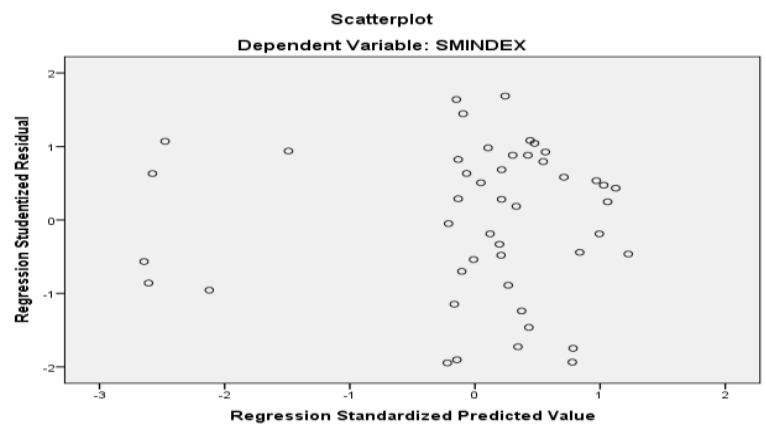

Sumber: Hasil Pengolahan Data SPSS 21.

Pada gambar 4.1 menunjukkan bahwa hasil uji heteroskedastisitas titik-titik menyebar secara acak dan tidak membentuk sebuah pola tertentu yang jelas. Hal ini dapat disimpulkan tidak terjadi heteroskedastisitas pada model regresi, sehingga model regresi ini layak dipakai.

\section{Analisis Regresi Linier Berganda}

Berdasarkan hasil pengujian analisis data yang memenuhi ada 55 data.Data 55 tersebut diolah kedalam analisis regresi linier berganda dengan hasil sebagai berikut:

Tabel 4.5

Uji Regresi Linier Berganda

Coefficients $^{\mathrm{a}}$

\begin{tabular}{|c|c|c|}
\hline \multirow[t]{2}{*}{ Model } & \multicolumn{2}{|c|}{$\begin{array}{l}\text { Unstandardized } \\
\text { Coefficients }\end{array}$} \\
\hline & B & Std. Error \\
\hline (Constant) & .250 & .047 \\
\hline LNPEMB & .030 & .005 \\
\hline 1 LNMUDA & .002 & .008 \\
\hline $\begin{array}{l}\text { LNOPERA } \\
\mathrm{S}\end{array}$ & -.026 & .011 \\
\hline
\end{tabular}

Sumber: Hasil Pengujian SPSS 21 
Berdasarkan hasil pengujian parameter individual yang disajikan dalam tabel diatas, maka dapat digunakan untuk persamaan regresi berikut ini:

$\mathrm{Y}=\mathrm{b} 0+\mathrm{b} 1$ (pembiayaan $)+\mathrm{b} 2($ simpanan mudharabah $)+\mathrm{b} 3$ (biaya operasional $)+\mathrm{e}$ $\mathrm{SMI}=0,250+0,030+0,002-0,026+0,04872$

Dari persamaan regresi diatas, maka dapat diuraikan sebagai berikut:

a. Konstanta sebesar 0,250 dengan arah hubungan positif menyatakan bahwa apabila variabel pembiayaan, simpanan mudharabah dan biaya operasional dalam keadaan konstan (tetap) maka smi (syariah muqasid index) yang diperoleh mengalami peningkatan sebesar 0,250.

b. Koefisien regresi b1 sebesar 0,030 dengan arah hubungannya positif menyatakan bahwa setiap kenaikan pembiayaan (musyarakah dan mudharabah) Rp. 1 maka akan meningkatkan kinerja smi( syariah muqasid index) sebesar 0,030 .

c. Koefisien regresi b2 sebesar 0,002 dengan arah hubungannya positif menyatakan bahwa setiap peningkatan Rp. 1 simpanan mudharabah akan meningkatkan kinerja smi (syariah muqasid index) sebesar 0,002.

d. Koefisien regresi b3 sebesar -0,026 dengan arah hubungannya negatif menyatakan bahwa setiap peningkatan biaya operasional maka akan menurunkan kinerja smi (syariah muqasid index) sebesar -0,026 dengan anggapan pembiayaan dan simpanan mudharabah tetap.

\section{Hasil dan Pembahasan Uji Hipotesis}

\section{Koefisien Determinasi $\left(\mathbf{R}^{2}\right)$}

Hasil uji koefisien determinasi adalah sebagai Berikut:

Tabel 4.6

Koefisien Determinasi

Model Summary ${ }^{b}$

\begin{tabular}{|l|l|}
\hline Model & $\begin{array}{l}\text { Adjusted } \\
\text { Square }\end{array}$ \\
\hline 1 & 492 \\
\hline
\end{tabular}

Sumber: Hasil Pengolahan Data SPSS 21. 
Berdasarkan tabel 4.6 diatas menunjukkan bahwa Adjusted R Square adalah 0,492, artinya 49,2\% variabel terikat syariah muqasid index (SMI) dijelaskan oleh variabel bebas yang terdiri dari pembiayaan, simpanan mudharabah dan biaya operasional dan sisanya 50,8\% dijelaskan oleh variabel lain diluar variabel yang digunakan.

\section{Hasil Uji Parsial (Uji t)}

Untuk mengetahui pengaruh variabel Pembiayaan, Simpanan Mudharabah, dan Biaya Operasional terhadap variabel terikat yaitu Syariah Muqasid Index maka perlu dilakukan uji t. Berdasarkan tabel dapat diketahui bahwa.

Tabel 4.7

Uji Parsial (Uji t)

\begin{tabular}{|ll|l|l|l|}
\hline Model & T & Sig. & Kesimpulan \\
\hline \multicolumn{2}{|l|}{ (Constant) } & 5.269 & .000 & \\
\multirow{2}{*}{1} & LNPEMB & 5.930 & .000 & H2 Diterima \\
& LNMUDAR & .272 & .787 & H3 Ditolak \\
& LNOPERAS & -2.289 & .027 & H4 Diterima \\
\hline
\end{tabular}

Sumber : Hasil Pengolahan Data SPSS 21.

Hasil pengujian dari tabel 4.7 diatas menunjukkan sebagai berikut:

H2: Variabel pembiayaan memiliki nilai signifikan 0,000 lebih kecil dari taraf signifikansi 0,05 (5\%). Hal ini menunjukkan bahwa pembiayaan berpengaruh terhadap syariah muqasid index (SMI). Dengan demikian berarti bahwa $\mathbf{H} \mathbf{2}$ diterima.

H3: Variabel simpanan mudharabah memiliki nilai signifikansi 0,787 lebih besar dari taraf signifikansi 0,05 (5\%). Hal ini menunjukkan bahwa simpanan mudharabah tidak berpengaruh terhadap syariah muqasid index (SMI). Dengan demikian berarti bahwa H3 ditolak.

H4: Variabel biaya operasional memiliki nilai signifikansi 0,027 lebih kecil dari taraf signifikansi $0,05(5 \%)$. Hal ini menunjukkan bahwa biaya operasional berpengaruh terhadap syariah muqasid index (SMI). Dengan demikian berarti bahwa $\mathbf{H 4}$ diterima. 


\section{Hasil Uji Simultan (Uji F)}

Hasil uji $\mathrm{F}$ adalah sebagai Berikut:

Tabel 4.8

Uji Simultan (Uji F)

ANOVA $^{\mathrm{a}}$

\begin{tabular}{|ll|l|l|l|}
\hline \multicolumn{2}{|l|}{ Model } & F & Sig. & Kesimpulan \\
\hline & $\begin{array}{l}\text { Regression } \\
\text { Residual } \\
\text { Total }\end{array}$ & 15.512 & $.000^{\mathrm{b}}$ & H1Diterima \\
& & & & \\
\hline
\end{tabular}

Sumber: Hasil Pengujian Data SPSS 21.

Dari hasil pengujian pada tabel 4.5 dapat dilihat pada nilai Fhitung sebesar 15.512 dan signifikan 0,000. Dengan menggunakan tingkat $a$ (alfa) 0,05 atau 5\%, maka $\mathrm{H}_{0}$ ditolak dan $\mathrm{H}_{1}$ diterima. Penolakan $\mathrm{H} 0$ dibuktikan dengan hasil perhitungan bahwa nilai sig $(0,000)<$ dari $a$ (alfa) $=0,05$, sehingga dapat disimpulkan bahwa variabel pembiayaan, simpanan mudharabah, dan biaya operasional secara bersama- sama (simultan) berpengaruh positif terhadap variabel syariah muqasid index. Dengan demikian berarti bahwa $\mathrm{H}_{1}$ diterima.

\section{KESIMPULAN}

Berdasarkan hasil pengujian dan pembahasan peneliti dapat meringkas hasil pada penelitian ini sebagai berikut:

1. Pembiayaan, simpanan mudharabah dan biaya operasional secara simultan berpengaruh terhadap syariah muqasid index dengan signifikansi sebesar 0,000. Hasil ini sesuai dengan H1 bahwa pembiayaan,simpanan mudharabah, dan biaya operasional secara simultan berpengaruh positif terhadap syariah muqasid index sehingga $\mathrm{H} 1$ diterima. Hal ini menunjukkan bahwa pembiayaan yang diberikan bank kepada nasabah, simpanan mudharabah yang diterima bank dari nasabah serta biaya-biaya operasional yang dikeluarkan bank dalam pelaksanaan kegiatan bank mempengaruhi kinerja syariah muqasid index sebesar 0,492 atau 49,2\%. Hal tersebut disebabkan karena pembiayaan secara langsung memberikan kemudahan bagi nasabah dalam menjalankan usaha yang nantinya keuntungannya akan dibagi, sesuai 
bagi hasil akad pembiayaan yang dipilih pada awal akad melalui bagi hasil syirkah muamanah. Selanjutnya bank umum syariah mengelola dana dari simpanan mudharabah, dana tersebut digunakan untuk pembiayaan, operasional bank dan lain sebagainya, akad simpanan mudharabah pada bank umum syariah ditentukan pada saat nasabah menyimpan uangnya dibank umum syariah yang dipilih, dan selanjutnya dari simpanan nasabah tersebut dana yang diterima di kelola oleh bank yang akan menghasilkan keuntungan dan keuntungan tersebut akan dibagi hasil dengan nasabah sesuai akad awal, dan bank tidak tahu kedepannya apakah dapat laba atau rugi. Selanjutnya bank mengeluarkan biaya - biaya operasional sesuai aktifitas kebutuhan bank. Sehingga kinerja syariah muqasid akan terlaksana dengan baik. Dengan demikian syariah muqasid index dipengaruhi oleh pembiayaan, simpanan mudharabah dan biaya operasional. Pembiayaan yang tinggi, simpanan mudhrabah yang rendah dengan biaya operasional yang efisien akan menghasilkan kinerja syariah muqasid index yang cukup tinggi.

2. Pembiayaan, secara simultan berpengaruh terhadap syariah muqasid index dengan signifikansi sebesar 0,000. Hasil ini sesuai dengan H2 bahwa pembiayaan secara simultan berpengaruh positif terhadap syariah muqasid index sehingga $\mathrm{H} 2$ diterima. Hasil penelitian ini sejalan dengan teori yang menyatakan penyaluran pembiayaan semakin banyak maka kinerja bank umum syariah akan semakin memiliki keuntungan bukan hanya laba dan ukuran keuangan melainkan memiliki nilai-nilai lain yaitu kesejahteraan dan menghindari keburukan. Karena kenaikkan pembiayaan maka akan menaikkan kinerja syariah muqasid index. Karena akad pembiayaan yang ditujukan diawal adalah akad pembiayaan bagi hasil, sehingga bank umum syariah memiliki kegiatan dengan porsi yang tinggi atau likuid maka hal ini kinerja syariah muqasid index akan naik. Dan hasil Penelitian ini sesuai dengan penelitian Imam Buchori dan Aji Prasetyo (2013) yang menyatakan tingkat pembiayaan mudharabah berpengaruh positif terhadap rasio profitabilitas. 
3. Simpanan mudharabah tidak berpengaruh positif terhadap syariah muqasid index sehingga H3 ditolak. Hal ini dapat dilihat dari prosentase simpanan mudharabah sebesar 0,787 atau 78,7\% yang berarti masih sedikit nasabah yang menginvestasikan dana dengan simpanan akad mudharabah dan nasabah lebih banyak menginvestasikan dana dengan memilih simpanan akad wadiah. Karena secara umum bank umum syariah belum memaksimalkan simpanan dalam bentuk akad mudharabah, sehingga kinerja smi (syariah muqasid index) mengalami penurunan. Simpanan mudharabah kecil karena akad nya tidak menarik sehingga hal tersebut mengakibatkan kinerja syariah muqasid index kecil. Dan simpanan mudharabah tidak langsung memberikan kontribusi ke dalam perhitungan rasio kinerja smi, karena simpanan yang didapatkan dari nasabah dikelola dananya oleh bank, dengan mengeluarkan pembiayaan yang dibutuhkan oleh nasabah. Sehingga simpanan mudharabah tidak berpengaruh langsung terhadap kinerja smi. Hal ini sejalan dengan penelitian Lutfiyah, Dina (2015) hasil penelitian menunjukkan bahwa tabungan mudharabah dan deposito mudharabah memiliki pengaruh tidak signifikan terhadap laba. Dengan mengoptimalkan kinerja muqasid syariah maka akan menghasilkan laba dan nilai yang sesuai dengan tujuan bank umum syariah.

4. Biaya operasional secara simultan berpengaruh positif terhadap syariah muqasid index dengan signifikansi sebesar 0,027 atau 2,7\% dengan nilai beta arah negative sebesar -0,026 sehingga $\mathrm{H} 4$ diterima. Biaya operasional dalam hal ini adalah biaya - biaya yang telah dikeluarkan oleh bank umum syariah dalam kegiatannya, baik kegiatan diluar bank maupun didalam bank. Dengan adanya pengeluaran biaya maka bank melakukan aktifitas kinerja yang nantinya akan menghasilkan suatu laba dan nilai. Biaya operasional yang efisien akan menghasilkan kinerja syariah muqasid index yang tinggi, karena dalam melakukan kegiatan atau aktifitas kerja tidak perlu biaya tinggi untuk kinerja yang baik, melainkan biaya yang rendah atau biaya efisien untuk kinerja yang maksimal dan kinerja yang baik. 
5. Temuan penelitian bahwa Variabel Pembiayaan dalam penelitian ini memiliki nilai tertinggi 0,788 atau 78,8\% dari pada variabel simpanan mudharabah dan biaya. Operasional, dengan nilai $78,8 \%$, hal ini berarti bahwa pembiayaan lebih mendominasi dan lebih mempengaruhi kinerja syariah muqasid index. Karena pendapatan bagi hasil pembiayaan yang diterima akan dioperasikan bank umum syariah sehingga kinerja bank akan terjadi. Temuan selanjutnya adalah biaya operasional memiliki nilai signifikansi 0,027 atau 2,7\% dengan nilai beta arah negative sebesar $-0,026$ hal ini berarti biaya operasional meningkat - 0,026 maka akan menurunkan kinerja -0,026. Biaya operasional yang efisien akan menghasilkan kinerja syariah muqasid index yang tinggi, karena dalam melakukan kegiatan atau aktifitas kerja tidak perlu biaya tinggi untuk kinerja yang baik, melainkan biaya yang rendah atau biaya efisien untuk kinerja yang maksimal dan kinerja yang baik.

\section{DAFTAR PUSTAKA}

Antonio, Muhammad Syafi'i. 2001 Bank Syariah Dari Teori ke Praktek, Gema Insani. Jakarta.

Chapra, M.U. and Ahmed, H. 2002. "Corporate Governance in Islamic Financial Institutions." Occasional Paper No. 6, Islamic Research and Training Institute/ Islamic Development Bank, Jeddah.

Chapra, U. 2001. The Future of Economics: An Islamic Perspective. The Islamic Foundations. Leicester. United Kingdom

Giannini, N. G. (2013). Faktor yang Mempengaruhi Pembiayaan Mudharabah pada Bank Umum Syariah di Indonesia. Accounting Analysis Journal , 2(1), p. 96 - 103.

Ghozali, Imam, 2011, Aplikasi MultiVariate Dengan Program SPSS, Badan Penerbit Universitas Diponegoro, Semarang.

Hadzmi, Muhammad Ihsan. "Analisis Pengaruh Nisbah Bagi Hasil dan Nilai Tukar Rupiah terhadap Tabungan Mudharabah Pada Perbankan Syariah 
Di Indonesia," Jurusan Ilmu Ekonomi dan Studi Pembangunan, Fakultas Ekonomi dan Bisnis UIN Syarif Hidayatullah, Jakarta, 2011.

Karim, Adiwarman. 2009. Bank Islam: Analisis Fiqih dan Keuangan. Edisi Ketiga. , Jakarta: Raja Grafindo Persada

Listyorini Wahyu Widati, Analisis Pengaruh Camel Terhadap Kinerja Perusahaan Perbankan Yang Go Publik, Jurnal Dinamika Akuntansi, Keuangan dan Perbankan, Volume1, No. 2,Nopember 2012

Mohammad, Mustafa Omar and Shahwan, Syahidawati. The Objective of Islamic Economic and Islamic Banking in Light of Maqasid Al-Shariah: A Critical Review, Middle East Journal of Scientific Research 13 (Research in ContemporaryIslamic Finance and Wealth Management): 75-84, 2013

Mohammed, Mustafa Omar, dkk. The Performance Measures of Islamic Bankinng Based on The Maqasid Framework, paper, prasented at the IIUM International Accounting Conference (INTAC IV) held at Putra Jaya Marroitt, 25 June 2008, hal. 1-29

Mohammed, Mustafa Omar \& Taib, Fauziah Md. Developing Islamic Banking Performance Measures Based On Maqasid Al-Shari'ah Framework: Case of 24 Selected Banks, Journal of Islamic Monetary Economics and Finance, August 2015, hal. 55-77

Pratami, Wuri Arianti Novi. “ Analisis Pengaruh Dana Pihak Ketiga (DPK), Capital Adequacy Ratio (CAR), Non Performing Financing (NPF) dan Return On Asset (ROA) terhadap Pembiayaan pada Perbankkan Syariah”. Fakultas Ekonomi Universitas Diponegoro, Semarang, 2011.

Purwaningsih, Farida. "Pengaruh Tabungan Mudharabah,Pembiayaan Mudharabah - Musyarakah dan Pendapatan Operasional Lainnya terhadap Laba pada Bank Jatim Syariah periode 2007-2015”. Jurusan Perbankkan Syariah, Fakultas Ekonomi dan Bisnis Islam Institut Agama Islam Negeri, Tulungagung, 2016.

Roza, Ida. (2015). “Analisa Perbandingan Kinerja perbankan Syariah dengan Metode Indeks Maqasid Syariah dan CAMEL”. Tesis UIN Sunan Kalijaga Yogyakarta. 
Samad, Abdus, and Hasan Kabir M.. 1999. "The Performance of Malaysian Islamic Bank During 1984- 1997: An Exploratory Study.“ International Journal of Islamic Financial Services. Vol. 1. No.3.

Sekaran, Uma. (2006). Research Methods For Business (Metode Penelitian Untuk Bisnis) Buku 2 Edisi 4. Jakarta: Salemba Empat.

Siddiqi, N. 1980. The Issues of Islamic Economics. Lahore, Pakistan

Sugiarti, Welthi, (2012), “Analisis Kinerja Keuangan dan Prediksi Tingkat Kesehatan Bank dengan Menggunakan Metode CAMEL pada Bank Umum yang Tercatat di Bursa Efek Indonesia”, Jurnal Akuntansi , Fakultas Ekonomi Universitas Gunadarma, Jakarta

Suharyanti, ST. "Analisis Pengaruh Nisbah Bagi Hasil, Inflasi, Pendapatan Nasional/PDB, dan SWBI Terhadap Tabungan Mudharabah Pada Perbankan Syariah Di Indonesia, Jurusan Ilmu Ekonomi dan Studi Pembangunan, Fakultas Ekonomi dan Bisnis UIN Syarif Hidayatullah, Jakarta, 2010.

Tohari, Achmad. "Analisis Pengaruh Nilai Tukar Rupiah terhadap Dollar, Inflasi, dan Jumlah Unag Beredar (M2) terhadap Dana Pihak Ketiga serta Impikasinya pada Pembiayaan Mudharabah Di Indonesia”, Jakarta, 2010.

Wisnu, Mawardi, (2005), “Analisis Faktor-faktor Yang Mempengaruhi Kinerja Keuangan Bank Umum di Indonesia (Studi Kasus Pada Bank Umum Dengan Total Assets Kurang Dari 1 Triliun)”, Jurnal Bisnis Dan Strategi, Vol.14. No.1.

Zahrah, Muhammad Abu. Ushul al-Fiqh, Kairo: Dar al-Fikr al- Arabi, 1997

$\underline{\text { www.google.com }}$

www.bi.go.id

www.ojk.co.id 